\title{
RECONFIGURING
}

\section{THE SILK ROAD}

New Research on East-West Exchange in Antiquity 



\title{
RECONFIGURING THE SILK ROAD
}

New Research on East-West Exchange in Antiquity

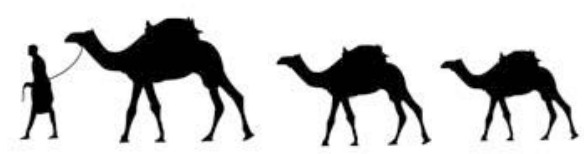

\author{
The Papers of a Symposium Held at the \\ University of Pennsylvania Museum of Archaeology and Anthropology \\ March 19, 2011 \\ Edited by \\ Victor H. Mair and Jane Hickman
}


(C) 2014 University of Pennsylvania Museum of Archaeology and Anthropology

Philadelphia, PA 19104-6324

Published for the University of Pennsylvania Museum by the University of Pennsylvania Press.

All rights reserved. Published 2014

CIP data is on file at the Library of Congress

ISBN-13: 978-1-934536-68-1

ISBN-10: 1-934536-68-7

The conference Reconfiguring the Silk Road: New Research on East-West Exchange in Antiquity, held at the University of Pennsylvania Museum of Archaeology and Anthropology on March 19,2011, was made possible by grants from the Henry Luce Foundation and the University of Pennsylvanias Center for Ancient Studies. The publication of the proceedings was funded by the Henry Luce Foundation.

The camel logo used throughout the book was drawn by Kevin Schott.

Printed in the United States of America on acid-free paper. 